\title{
13. Limited, fragmented and powerless: national urban policies in Sweden
}

Anders Lidström and Nils Hertting

\section{INTRODUCTION}

In a comparative overview of national urban policies in different countries, the OECD bluntly stated that 'Sweden does not have a national urban policy' (OECD 2017, p. 119). There are national initiatives that concern urban matters and aim at stimulating urban development, but these have only a low degree of coherence and consistency over time in terms of substantive priorities and no permanent institutional fixation at the national level. A repeated strategy is to launch temporary national projects for stimulating local, more or less informal collaboration across more established policy fields of the Swedish welfare state without interfering with the strong tradition of local self-government. Moreover, such coordination problems seem to be more urgent in large cities. In that sense, national urban policy in Sweden stresses an institutional rather than a substantive aim.

Is this simply a coincidence, or is there instead a rational logic behind the unwillingness to formulate a coherent national urban policy in Sweden, despite the growing welfare challenges in the nation's metropolitan areas? This chapter describes the logic of national urban policy initiatives in Sweden and explores the reasons behind the lack of a strong national agenda for urban areas.

\subsection{The Position of Local and Regional Governments and Recent Reforms with an Urban Impact}

The Swedish system of local government comprises two tiers, the 290 municipalities and the 21 regions. The regions were previously called county councils, but after being given additional responsibility for regional development policies, they have now all been renamed as regions.

Both municipalities and regions are directly elected units of local self-government. They have mandatory as well as voluntary functions. Municipalities, which represent about two-thirds of the total local government 
expenditures, are in charge of major welfare functions such as elderly care, child care and primary and secondary education. They also have a planning monopoly, that is, the right (within the law) to decide for what purpose all land within the municipal borders should be used, and the right to grant building permits. In addition, they are responsible for infrastructure such as streets and roads, for sewage and refuse, and for cultural and leisure institutions. For regions, the main function is health care, but regions are also in charge of public dental services, regional development, public transport and cultural institutions. The main source of local government income is a proportional income tax, which is set autonomously by each local and regional council. Central government provides additional grants, mainly to contribute to the financing of the welfare functions. In total, Swedish local governments represent about a quarter of the GDP and almost half of total public spending. Local governments have a constitutional protection, although this does not include the right to challenge central government in the courts (Lidström 2016).

In a comparative European perspective, Swedish local government is among the strongest in Europe (Loughlin, Hendriks and Lidström 2011). Despite its key role in the national welfare system, it is generally regarded as having a high degree of autonomy. The expert-based Local Autonomy Index ranks the position of Swedish municipalities as fourth among 39 investigated European countries (Ladner et al. 2019). The system also stands out as exceptional in the way it relies on political parties and collective decision-making. All councillors must represent a political party. Although 95 per cent of the local and regional councillors represent one of the parties that are in the national Parliament, there are also local parties that have been formed to address local issues. The strong role of the political parties is also expressed as a dominance of collective forms of decision-making. All decisions in a local authority are undertaken by collective bodies, which means that there is no correspondence with the individual powers held by continental mayors. For the same reasons, means of local direct democracy and popular support for such means are weak in Sweden (Lidström 2016; Hertting and Klijn 2017).

In order to strengthen the municipalities and better prepare them for taking on expanding welfare responsibilities, they have been the subjects of comprehensive territorial reforms on two occasions - in 1952 and 1974. After the second reform, a previous distinction between rural and urban municipalities was abolished and replaced by just one type of municipality that usually comprises both built-up areas and rural countryside. Since then, the term 'cities' has had no administrative status in national legislation.

The regional level of government has also been reformed through a gradual process that was finally completed in 2019. This began with an amalgamation of four county councils in West Sweden to establish the region of Västra Götaland and with the merging of two counties in the very south to form the 
Skåne region. Urbanization and an increase in commuting areas had made previous borders obsolete as people could cross several county borders on their way to work. Setting up larger regions was a way of coming to terms with this territorial mismatch. The new regions were given additional responsibility for regional development policies along with their previous health care responsibilities (Lidström 2010).

The Västra Götaland and Skåne reforms were followed by two attempts to carry out corresponding reforms for the country as a whole. All county councils would be replaced by six to nine larger regions with additional regional development functions. The aim was to improve the capacity of the intermediate level of government and to solve remaining problems of mismatch between administrative borders and commuting areas. Perhaps surprisingly, the Stockholm commuting area would have been exempted. The commuting area around Stockholm has for a long time superseded the county of Stockholm and currently involves four different counties. In the rest of the country, there was a fear that a mega metropolitan region for the whole of greater Stockholm would be too dominant, and therefore most suggestions for regional reform included dividing this area into two regions - usually a core close to the city of Stockholm and the outer commuting area.

However, both attempts to implement a comprehensive reform failed. The first initiative, taken by a Social Democratic government, was effectively stopped when a non-socialist government came into power in 2006. When the Social Democrats returned to power in 2014, in a minority coalition with the Environmental Party, the issue was again raised, but it soon turned out that there was no majority in the Parliament for the reform. Nevertheless, there was support for transferring the main responsibility for regional development functions from central government units at the county level to the elected county councils but without any changes of borders. After the completion of this reform in 2019, county councils are now officially called regions. However, the problem with the mismatch between commuting hinterlands and regional borders in parts of the country and, in particular, in Greater Stockholm have not been solved.

Local governments in urban areas are not entrusted with any functions other than those related to local government generally. Nor are there any compulsory units of inter-municipal cooperation in urban areas as in, for example, France. Where such units exist, they are entirely initiated by the municipalities themselves. For example, the Göteborg region, comprising the city of Göteborg and the surrounding 12 municipalities, with a total population of almost one million inhabitants, coordinates tasks such as regional planning, upper secondary education and EU lobbying for the member municipalities. Another example is the Umeå region, which comprises Umeå and six municipalities in the commuting hinterland. There is no corresponding unit for Greater 
Stockholm, although the Mälardalen board functions as a joint meeting place for municipalities and regions around Lake Mälaren close to Stockholm. There are units of inter-municipal cooperation within parts of Greater Stockholm, for example for fire protection.

Another feature of Swedish local and regional government is the weakness of regional planning instruments for metropolitan areas. Although there are means for regional planning in the two largest metropolitan areas of Stockholm and Göteborg, these typically cover a smaller territory than the full commuting area. The municipalities take part in the planning process but are not bound to comply with its results. As the municipalities hold the planning monopoly, they make the final decisions about land use. Particularly controversial has been the issue of housing planning. With a general shortage of housing in the metropolitan areas, some municipalities have decided to build only housing that attracts mainly middle- and high-income earners, thereby avoiding an influx of less well-off citizens. However, there is currently a tendency to slightly strengthen the regional planning instruments, for example by coordinating them with regional development plans, although such plans remain advisory.

To summarize, the system of local and regional government in Sweden is not aligned with the specific conditions that exist in the urban areas. Further, inter-municipal cooperation has been initiated from below rather than by the national government. Municipalities have a key role, and instruments for regional planning are weak. Central government has been hesitant to intervene in urban matters other than through temporary financial incentives and recommendations. Although attempts have been made to formulate a national urban policy in Sweden, these have tended to be weak to avoid challenging the historically strong position of local self-government. This is a major reason for the absence of a strong national urban policy in Sweden.

\subsection{Current Challenges of Urban Areas as Defined in a National Agenda}

Documents from central government, national agencies and local authorities are fairly consistent with regard to the most important urban challenges facing Sweden. References are generally made to the need for sustainable development of housing and infrastructure, the need to counteract urban deprivation, segregation and violence, and the challenges linked to a widening urban-rural division.

The first challenge, the need for sustainable development of housing and infrastructure, is a response to the general expansion of the metropolitan areas. Population growth in the post-industrial era has typically occurred mainly in the three largest metropolitan regions and the university cities. The rural countryside beyond these areas has suffered from population losses, but many 
small- and medium-sized towns have also stagnated. A major driver in this phase of urbanization is the demand for skilled and well-educated labour in the expanding knowledge-based trades and the specialization of the labour force (Sveriges Kommuner och Landsting 2015; Westlund 2014). The metropolitan areas also attract new immigrants as these areas offer somewhat better employment opportunities as well as stronger communities of people of similar ethnicities.

In order to host the large influx of new arrivals to the metropolitan regions, new housing is constantly required together with an expansion of services and communication infrastructure. A special challenge related to housing development in the largest metropolitan areas is to ensure that all municipalities contribute by developing housing for all income groups. Wealthy municipalities in the Greater Stockholm area have rejected offers of new traffic infrastructure as this would involve opening up new areas of rented housing. The planning monopoly that gives the municipalities the final say about how the land within its borders can be used has a strong tradition and is a key element in local self-government.

All this development needs to be environmentally sustainable. It is recognized that new housing and infrastructure should contribute to reducing rather than increasing carbon emissions, support the use of renewable energy and natural resources, and enhance sustainable forms of transportation and living (Swedish Government 2018).

A second challenge in the urban areas is the increasing segregation of rich and poor territories, social tensions, and the increase of violence in the most vulnerable areas of the major cities and their suburbs. Although still a country with a relatively equal income distribution, inequalities increased more in Sweden than in any other OECD country between 1985 and 2010 (OECD 2015). The territorial consequences of these changes is a growing differentiation in the ability to pay for housing, which leads to increasing segregation. This type of separation also has an ethnic component as non-European immigrants, in particular, are socially at greater risk of unemployment and poverty and are overrepresented in the poorest areas. There are also incidents of violence and unrest in some of the most vulnerable areas. Swedish police authorities have targeted 60 housing areas as being particularly exposed. Although both national and local policies have been developed to counteract segregation and its consequences, these have not been successful in the past (Lidström 2017).

A third urban challenge concerns the increasing tensions between urban and rural areas in Sweden, effectively dividing the country in two (Sveriges Kommuner och Landsting 2015). The rural countryside and smaller towns outside the metropolitan areas and university cities have become trapped in a downward spiral of negative population development. Although the periph- 
eral municipalities are compensated for their higher costs for welfare provision through a system of municipal equalization, this is not sufficient to stop the erosion of services in these areas. In addition, these areas have a much less varied labour market.

The negative population development in the countryside has coincided with a restructuring of employment opportunities, in particular with the reduction of industrial employment. This has contributed to the sense of frustration experienced by many people living outside large cities who feel abandoned by national decision-makers and see themselves as victims in a rapidly changing world. In Sweden as well as in other countries, it has also contributed to the growth of anti-immigration and populist parties (Rydgren and Ruth 2013).

\section{SUCCESSIVE NATIONAL POLICY INITIATIVES}

As previously suggested, it is hardly relevant to discuss a comprehensive and explicit national urban policy in Sweden. As this section will illuminate, it is also difficult, therefore, to trace a clear path of evolvement. It is more accurate to describe Swedish national urban policy initiatives as several, sometimes parallel, projects and selective attempts to temporarily complement the more general policies and services of the Swedish welfare state, acknowledging the role of local self-government. Furthermore, although the goal has often been framed in terms of substantive outcomes such as 'breaking segregation' (social sustainability), growth (economic sustainability), and more recently climate change and adaptation (ecological sustainability), a recurrent theme of these attempts is an aim for coordination and mutual adjustment between different public agencies, and between public, private and civil actors. Hence, national urban policy initiatives in Sweden seem to have as many institutional as substantial aims. Below we will describe these features by highlighting several of the major national urban policy initiatives from the late 1990s to 2017.

During the 1990s, a number of governmental urban policy investigations and programmes for area-based projects within larger cities were carried out (The Metropolitan Investigation 1990; Metropolitan Committee 1998). In the Swedish context, the area-based ideas were innovative in the sense that not only were peripheral regions with decreasing populations and related economic problems targeted for extra support, but also the three largest city regions, that is, Stockholm, Göteborg and Malmö (Andersson 2006). The strategy culminated in the Metropolitan Initiative (Storstadssatsningen), carried out between 1998 and 2006 (Palander 2006).

The Metropolitan Initiative had the dual ambition of reducing residential segregation and inducing growth in seven municipalities located in the three most urbanized areas in Sweden. More precisely, it aimed to (1) 'give the metropolitan regions good opportunities for growth and thus be able to con- 
tribute to new jobs being created both within the regions and in other parts of the country' and (2) to 'break the social and ethnic discriminatory segregation in the metropolitan regions and promote equal living conditions for the inhabitants of large cities' (Swedish Government 1998, p. 30). It was claimed that a characteristic of the metropolitan city 'is that problems are primarily about the growing gaps between those who have and those who lack work and own income and between native and foreign-born people' (Swedish Government 1998, p. 31). The urban policy problem was described as a 'divided society' characterized by mistrust, irresponsibility, social tensions, insecurity and crime.

The two general goals were operationalized into 13 more precise aims, including that Swedish metropolitan regions should be able to do well in the competition for establishments and investments compared to other European metropolitan regions, and that the employment rate in the socially disadvantaged residential areas should increase for both men and women (Swedish Government 1998, pp. 30f). In short, the Metropolitan Initiative was a broad catalogue - an umbrella - of objectives that related to many, if not most, policy sectors of the Swedish welfare state (Hertting and Vedung 2009).

As the key implementation mechanism of the initiative, local development agreements (lokala utvecklingsavtal) were introduced. This innovation was launched as a Swedish contribution to the EU Commission's Peer Review process in order for it to be spread among the Member States as 'best practice'. The underlying doctrine was quite sophisticated (Hertting and Vedung 2009). The national government's catalogue of goals, combined with economic 'carrots' and informative sermons, aimed to trigger plans for neighbourhood development by involving different types of actors at the local level. The plans were assembled by the municipalities as the basis for negotiations with the national government, which eventually rendered local development agreements. The interministerial Metropolitan Delegation was organized within the government to handle the practical aspects of governing through local development agreements. The local development agreements were transformed into approximately one thousand smaller projects with a variety of local actors (municipal, state, private, residents) involved.

To be fair, local development agreements as an urban policy measure were not entirely new. The idea had been tested on a small scale in the early 1990s but was radically scaled up in the Metropolitan Initiative. When the programme ended eight years later in 2006, more than SEK four billion had been invested in projects through local development agreements. Despite its temporary character, the Metropolitan Initiative had long-term goals. The explicit idea was that the agreements should serve as a vehicle for 'meta-governance' (Hertting and Vedung 2009, p. 199) and a stimulator of continued voluntary area-based local collaboration. Hence, after eight years with state grants through the 
development agreements, local public, private and civil actors were expected to continue to conduct coordinated development but without the additional national resources. The long-term goal of reducing segregation should now be achieved with the existing legal framework and within ordinary financial resources of national and local authorities, the Social Democratic government declared in its budget proposal in 2005.

In October 2006, a new non-socialist government was installed, and a few years later, the Urban Development Policy was presented as a new 'policy area' in the Swedish national budget. Urbanity was seen as enhancing economic growth, and the focus was on the development of socially deprived urban neighbourhoods. No extra money was allocated, but within their regular frameworks, the various national authorities for employment, policing and social insurance were instructed to collaborate with local actors. Hence, instead of continuing with local collaboration and local development agreements developed through negotiations with municipalities, the initiative was now coming from above.

In the coming years, faith in these kinds of area-focused national urban policy initiatives gradually faded. The evaluations of both the Metropolitan Initiative and the Urban Development Policy did not offer much evidence of progress. In an evaluation from 2012, the National Authority of Housing concluded, "the urban development work is characterized by contradictory goal formulations. The actors in the city districts almost daily face goal conflicts. (...) Short-term efforts that address symptoms rather than the underlying causes risk being constantly in conflict with long-term goals' (Boverket 2013).

During the same period, the overall urban policy agenda started to change. Environmental goals and climate change were added as important aims of the national decisions that were framed as urban policy. For instance, a new Delegation for Sustainable Cities was established with the main aim of stimulating construction projects that could reduce greenhouse gas emissions. Again, local collaboration between a range of local public, private and civil actors was regarded as a key measure, if not an aim in itself. The purpose was to establish an arena for cooperation, an exchange of experience, and knowledge dissemination across sector boundaries. Between 2008 and 2012, a total of 98 local projects received support.

The Delegation for Sustainable Cities followed a logic similar to that of the Metropolitan Initiative by using temporary pushes to realize 'a holistic view, collaboration and organizational system thinking, as opposed to today's sector-based downpipe thinking and downpipe action where every actor prioritizes his or her special interest, and each problem is handled separately from other problems' (Delegation for Sustainable Cities 2012, p. 16). However, in terms of financial resources, the delegation did not even come close to having those that were at the disposal of the Metropolitan Initiative. 
A further measure was the Swedish Urban Development Platform, which was a joint effort by several central government agencies aiming at coordinating and stimulating sustainable growth through knowledge sharing and collaboration. It was launched in 2014, coordinated by the National Board of Housing, Building and Planning (Boverket), and it involved Sweden's 13 largest cities. The platform was connected to the EU URBACT programme that attempted to foster sustainable integrated urban development in cities across Europe.

The next initiative came in 2017, when the government established the Council for Sustainable Cities. This was a forum comprising a large number of national sector agencies with the aim of supporting municipalities in their work on long-term sustainable urban and social development. Its overall ambition was to develop and suggest strategies for the implementation of the new national policy for 'Living Cities' (Swedish Government 2018). The objective of handling the several different dimensions of sustainability at the same time was emphasized more explicitly than before:

Sustainable urban development is based on a holistic view of how cities should cover environmental, social and economic dimensions. It is about achieving good habitats, i.e. well-functioning and robust cities designed so that they are for everyone. The design of the physical environment can contribute to reducing segregation, increasing social cohesion and providing the conditions for achieving national climate and environmental goals. (Swedish Government 2018, p. 4)

Compared to previous national urban policy initiatives, the focus was now much more on ecological aspects. In accordance with international policy discourses, the city is simultaneously framed as a climate problem and a climate change solution:

Especially in cities, proximity and accessibility to different functions make it possible for more people to manage their everyday life without their own car and thus it is possible to increase the proportion of transports that take place by public transport, walking and cycling. Traffic planning, regarding both passenger and freight transport, is therefore a central part of a national policy for sustainable urban development. (Swedish Government 2018, p. 4)

Although the aim of the Strategy for Liveable Cities is to outline a new and coherent national policy for sustainable cities, the general impression is one of remaining fragmentation. Indeed, no fewer than 45 different policy measures are mentioned as relevant for the implementation of the strategy.

A parallel effort by central government has been to enhance the building of new residential housing through joint funding of local and regional infrastructure. As the municipalities have the planning monopoly, central government has attempted to stimulate new housing development through co-funding of 
traffic infrastructure. One example is the National Negotiation on Housing and Infrastructure, which is a series of agreements between central government and regional and local authorities aiming at improving the urban infrastructure. Major infrastructure projects have been initiated and are underway in Greater Stockholm, Göteborg and Malmö, including new railways, subways and highways. Central government promises to co-finance new traffic infrastructure if local governments commit to housing development. The National Negotiation has also made agreements with local and regional interests in order to establish a high-speed rail network between the three major cities (OECD 2018).

Although the support for the municipal planning monopoly is strong, the need for a regional perspective on housing development is gaining support. In the latest revision of the Planning Act in 2018, regional planning instruments were made compulsory, initially in Greater Stockholm and in the Skåne region, although these still remain only advisory. These instruments are likely to be followed by corresponding requirements in other parts of the country.

As this overview has illustrated, although central government and national agencies have initiated policies targeting urban and metropolitan areas in Sweden, these are far from comprehensive or direct (d'Albergo 2010). Typical for urban policies in Sweden, these programmes contain no instruments of intervention from central government but are instead a list of various means to stimulate development, mainly through targeted financial support to municipalities or via initiatives to coordinate different public and private actors.

\section{WHICH ACTORS ARE DRIVING THE CHANGES?}

Not only is coherent national urban policy missing in Sweden; notably, none of the national political parties are pursuing any such agenda. The political parties provide extensive lists on their websites of all policy areas for which they have statements, but none of them identify metropolitan, urban or city policies (storstadpolitik, stadspolitik, urban politik) as distinctive policy areas. Although they all pursue policies that concern the urban space, this is presented under more restricted labels such as housing policy, public transport, infrastructure, segregation and socially exposed areas.

Despite the lack of interest from the national political parties, successive governments consisting of these parties, both socialist and non-socialist, have initiated relatively comprehensive urban programmes, some of which have been discussed in the previous section. For example, a Social Democratic government launched the Metropolitan Initiative, whereas the Urban Development Policy was initiated by a non-socialist government. The Strategy for Liveable Cities was the proposal of a Social Democratic-Environmental Party coalition (Swedish Government 2018). 
This type of weak urban policy is also in line with the demands of the interest organization that represents Swedish local governments, the Swedish Association of Local and Regional Governments (SALAR). They favour a national urban policy that provides preconditions for the development of sustainable cities and towns but refrains from interfering with sub-national self-government. Instead, it should originate from and support the municipal and regional levels of government. National urban policies should respect the principle of subsidiarity and local self-government. This type of urban policy has also been requested by civil society organizations, such as those representing architects and real estate interests. In 2011, three national authorities, the National Board of Housing, Building and Planning; Formas (the research council for sustainable development); and the Swedish Museum of Architecture suggested that the Swedish government should develop a national urban policy. A key argument was that it was needed to overcome sector boundaries and to coordinate state and municipal initiatives.

EU urban initiatives have been influential for the Swedish policy, at least in the sense that the government explicitly refers to the EU in its Strategy for Liveable Cities (Swedish Government 2018). EU initiatives include the Urban Agenda that aims at stimulating sustainable urban development, the structural funds that are increasingly being used to address urban problems, and the interregional cooperation within the URBACT programme. These programmes emphasize voluntary coordination of networks, development of knowledge for sustainable cities, and the sharing of experiences. However, during the programme period 2014-2020, urban development has also become increasingly important within the EU cohesion policies. Urban initiatives have been prioritized by the structural funds covering the three Swedish metropolitan areas of Stockholm, Göteborg and Malmö. Resources are allocated to support entrepreneurship, innovation and a carbon-free economy (Swedish Government 2018).

\section{SPECIFIC POLICIES}

\subsection{Urban Housing Crisis, National Housing Policy Discourse and Local Housing Responses}

On the one hand, housing policy has been a pivotal part of the Swedish universal welfare model. On the other, the intervention logic of housing policy has always been deviant in relation to most other welfare sectors, such as social and school policy. The current housing policy goal was formulated by the Parliament in 2008. It states that the ultimate aim of Sweden's housing policy is to provide 'well-functioning housing markets where consumers are offered a range of housing that meets their needs'. Notably, it stresses that housing 
for all should be distributed through markets. However, this formulation is not a reflection of the New Public Management era but instead originated in the late 1940s, when national housing policy established that government should stay away from direct public allocation of housing (as a legal right and through authoritative decisions). Following political scientist Bo Bengtsson's argument, in contrast to more dualistic housing policy systems, with a profiled social housing sector as a complement to the open housing market, the logic of the Swedish housing model is that the state provides correctives, in terms of subsidies or regulations, in order to make housing available to all types of households in one universal housing market (Bengtsson 2015). Housing consumers should not be categorized by income or living conditions.

While this overall housing policy doctrine has remained remarkably stable at the national level, and suggestions for a more selective policy of 'social housing' have thus far been rejected by all political parties, since the 1990s a number of partial and incremental reforms of the Swedish housing regime seem to have undermined the ability to implement the idea locally. Today many observers refer to the current housing regime as a dysfunctional and ill-structured patchwork of recent policy decisions and traditional housing policy norms (Christophers 2013). To some, the current housing crisis is an outcome of neoliberal reforms and an increasing trust in market mechanisms and businesslike public housing (Listerborn 2018); to others, lack of a free housing market is the explanation for the suboptimal use of the housing stock (Kopsch 2019).

A key instrument of the Swedish housing doctrine has been municipality-owned housing companies (Bengtsson 2015). These are public housing organizations, not aimed at delivering social housing but with the task of offering rental housing of high quality for the benefit of everyone. One of the changes of government policy, linked to European competition law, has gradually undermined the special position of these housing companies and the economic benefits that they previously enjoyed (Grander 2017; Christophers 2013). The new situation meant that the municipalities took over part of the financial risk previously incurred by the state and, therefore, started to act in a more businesslike manner. One strategy of municipality-owned housing companies, particularly in the metropolitan area of Stockholm, was to sell off attractive parts of their housing stock. By economic necessity or ideological ('right to buy') conviction, the consequence, it has been argued, is that their ability to contribute to an integrated and unitary housing market for all is threatened. Although the national political discourse does not include references to social housing, it is argued that public housing is nevertheless becoming 'social by default' (Magnusson and Turner 2008; Grander 2017).

At the same time, the increased financial risks undertaken by the municipalities are transformed into higher demands on potential tenants, making it harder 
for disadvantaged groups to gain access to housing on the ordinary housing market. As a result, a more dualistic housing regime is now emerging, especially in the urban areas. According to the Swedish Housing Agency, in 2019 most municipalities are providing 'social contracts', that is, housing allocated by social services for people who are not approved as tenants in the ordinary housing market.

This development of municipality-owned housing companies is interesting and highlights how Swedish national urban policy takes place in the shadow of the principle of local self-government. In 1999 and again in 2002, the Social Democratic government attempted to stop the selling of the municipal housing stock through a special act. The strategy was effective in the short term but did not gain legitimacy and had limited long-term effects. It was harshly criticized by the Swedish Association of Local and Regional Government and referred to as an illegitimate restriction of the Swedish local self-government doctrine.

\subsection{Urban Transport and the Urban Environment Agreements}

Urban transport is repeatedly described as a key to sustainable cities. Good communication systems contribute not only to economic productivity but also to social cohesion and, perhaps most importantly, to a climate-smart city. The Urban Environment Agreements (stadsmiljöavtal) are a national initiative through which Swedish municipalities and regions can apply for funding for innovative solutions for public transport, walking and cycling. The aim of the initiative is to promote sustainable urban environments by providing support that leads to (1) an increased proportion of passenger transport by public transport or bicycle traffic and (2) sustainable freight transport solutions.

The policy was launched in 2015 and is being implemented by the Swedish Transport Agency. In line with a long tradition of negotiating large infrastructure projects between the state and municipalities, it works mainly through economic guidance mechanisms, and for the period 2018-2029, the Urban Environment Agreements have been allocated SEK 12 billion in the national plan for the transport system.

The national financial support should promote innovative, capacity-efficient and resource-efficient solutions for public or bicycle traffic and efforts to coordinate and improve the efficiency of freight transport. In order to receive support, the municipality must contribute with own investments in the urban environment. These local investments can include centrally located buildings, parking strategies etc. within the mandate of local government. It is such combinations of national and local investments in different aspects of specific urban environments that make up an Urban Environment Agreement.

Two aspects of the Urban Environment Agreements are of particular interest in this context. First, the Urban Environment Agreement is also a device to 
press for a more holistic approach across municipality jurisdictions in order to promote a sustainable urban environment. Second, through the request that municipalities provide additional services and investments, a traffic policy instrument effectively becomes a means by which the national government can entice urban municipalities to build certain types of housing. In the context of the planning monopoly of Swedish municipalities and the lack of a national housing plan or effective regional housing plans, this type of contract governance gives the national government the capacity to, at least temporarily, buy influence over urban policy problems that otherwise would have been beyond its reach. At the local level, however, these negotiations between national government agencies and leading local politicians are not without controversy. They are claimed to shortcut local democracy and, once again, illustrate the tension between the norm of local self-government, on the one hand, and the necessity for national coordination and guidance in order to solve urban problems, on the other hand.

\section{CONCLUSIONS}

As mentioned initially in this chapter, the OECD has come to the conclusion that there is no national urban policy in Sweden. However, this review suggests that there is, indeed, such a policy, but that it is highly fragmented and relatively powerless, taking place in the shadow of a strong system and tradition of local self-government. The policy is characterized by several features.

First, whether it is relevant to talk about an evolvement towards a more comprehensive national urban policy in Sweden is doubtful. The major Swedish urban policy initiatives have always had several parallel substantive policy orientations rather than a clear prioritization, while the combinations of aims have, at the same time, changed over time. Economic growth and segregation have lately been complemented by ecological and climate change concerns. (In passing, with such broad and ambiguous goals, it is not surprising that evaluations of Swedish national urban policy often render a pessimistic conclusion. The more goals a programme has and the more divergent these goals are, the less likely the programme will appear as successful in evaluations.)

Second, instead of clear substantive prioritizations, Swedish national urban policy initiatives seem to be driven by the aim to handle the silo problem and stress the importance of cross-sectoral and holistic collaboration at the local level. Taken together, Swedish urban policy has been more a strategy to enhance the implementation of other established sectoral policy goals through improved coordination than a substantive policy goal in itself.

A third observation concerns the organization of urban policy at the national level in Sweden. All major initiatives in the field since the 1990s have been organized as temporal arrangements outside the regular authorities and institu- 
tions of the Swedish governmental organization. Over and over again, national urban policy instruments have been designed to initiate rather than implement urban development processes. Given the fragmented ambitions of the policy initiatives, this seems quite logical. It is difficult to host such an agenda within a highly sectorized structure and even to prioritize such ambiguous aims in the context of the more established welfare sectors.

Finally, the attempts to develop national urban policies have taken place in the shadow of a strong and constitutionally secured position for local self-government. It has been obvious through the years that no government has been prepared to challenge this position, for example by directly intervening, by introducing stronger regulation or by limiting the municipal planning monopoly. Rather, national government has relied on voluntary cooperation and financial incentives to make local governments align with national priorities.

\section{REFERENCES}

Andersson, R. (2006), 'Breaking segregation - rhetorical construct or effective policy? The case of the Metropolitan Development Initiative in Sweden', Urban Studies, $\mathbf{4 3}$ (4), 787-799.

Bengtsson, B. (2015), 'Allmännyttan och bostadspolitiken i går, i dag och i morgon - institutionella förutsättningar i förändring' [Public housing and housing policy yesterday, today and tomorrow - institutional conditions in transition], in T. Salonen (ed.), Nyttan med allmännyttan, Stockholm: Liber, pp. 25-48.

Boverket (2013), Urbant utvecklingsarbete [Urban Development Tasks], Rapport 2013:6 (Regeringsuppdrag).

Christophers, B. (2013), 'A monstrous hybrid: The political economy of housing in early twenty-first century Sweden', New Political Economy, 18 (6), 885-911.

D'Albergo, E. (2010), 'Urban issues in nation-state agendas: A comparison in Western Europe', Urban Research and Practice, 3 (2), 138-158.

Delegation for Sustainable Cities (Delegationen för Hållbara Städer) (2012), Femton hinder för hållbar stadsutveckling [Fifteen Obstacles to Sustainable Urban Development], SOU M 2011:01/2012/66.

Grander, M. (2017), 'New public housing: A selective model disguised as universal? Implications of the market adaptation of Swedish public housing', International Journal of Housing Policy, 17 (3), 335-352.

Hertting, N. and E-H. Klijn (2017), 'Institutionalization of local participatory governance in France, the Netherlands, and Sweden: Three arguments reconsidered', in N. Hertting and C. Kugelberg (eds), Local Participatory Governance and Representative Democracy, Routledge: London, pp. 168-194.

Hertting, N. and E. Vedung (2009), Den utvärderingstäta politiken: styrning och utvärdering $i$ svensk storstadspolitik [Evaluation-intensive Policy: Governance and Evaluation in Swedish Metropolitan Policy], Lund: Studentlitteratur.

Kopsch, F. (2019), En hyresmarknad $i$ kris. Fortsätt lindra symptomen eller bota sjukdomen? [A Housing Market in Crisis. Continue Easing the Symptoms or Cure the Disease?], Stockholm: SNS. 
Ladner, A., N. Keuffer, H. Baldersheim, N. Hlepas, P. Swianiewicz, K. Steyvers and C. Navarro (2019), Patterns of Local Autonomy in Europe, London: Palgrave Macmillan.

Lidström, A. (2010), 'The Swedish model under stress: The waning of the egalitarian, unitary state?', in L. Rose and H. Baldersheim (eds), Territorial Choice: The Politics of Boundaries and Borders, Basingstoke: Palgrave Macmillan, pp. 61-79.

Lidström, A. (2016), 'Swedish local and regional government in a European context', in Jon Pierre (ed.), The Oxford Handbook of Swedish Politics, Oxford: Oxford University Press, pp. 261-281.

Lidström, A. (2017), 'The equal metropolis? Can social policies counteract diversity in Swedish metropolitan settings?', in J. Sellers, M. Arretche, D. Kübler and E. Razin (eds), Inequality and Governance in the Metropolis: Place Equality Regimes and Fiscal Choices in Eleven Countries, London: Palgrave Macmillan, pp. 237-252.

Listerborn, C. (2018), Bostadsojämlikhet. Röster om bostadsnöden [Housing Inequality. Voices on Housing Misery], Stockholm: Premiss Förlag.

Loughlin, J., F. Hendriks and A. Lidström (eds) (2011), The Oxford Handbook of Local and Regional Democracy in Europe, Oxford: Oxford University Press.

Magnusson, L. and B. Turner (2008), 'Municipal housing companies in Sweden social by default', Housing, Theory and Society, 25 (4), 275-296.

Metropolitan Committee (Storstadskommittén) (1998), Tre städer. En storstadspolitik för hela landet [Three Cities. A Metropolitan Policy for the Whole Country]. SOU 1998:25.

OECD (2015), In It Together: Why Less Inequality Benefits All, Paris: OECD Publishing.

OECD (2017), National Urban Policy in OECD Countries, Paris: OECD Publishing.

OECD (2018), OECD Territorial Reviews: The Megaregion of Western Scandinavia, Paris: OECD Publishing.

Palander, C. (2006), Områdesbaserad politik för minskad segregation. En studie av den svenska storstadspolitiken[Area-Based Policy for Reduced Segregation. A Study of the Swedish Metropolitan Policy], Dissertation, Department of Social and Economic Geography, Uppsala University, Uppsala.

Rydgren, J. and P. Ruth (2013), 'Contextual explanations of radical right-wing support in Sweden: Socioeconomic marginalization, group threat, and the halo effect', Ethnic and Racial Studies, 36 (4), 711-728.

Sveriges Kommuner och Landsting (2015), Urbanisering. Utmaningar för kommuner med växande och minskande befolkning[Urbanisation. Challenges for Municipalities with Growing and Shrinking Populations], Stockholm: SKL.

Swedish Government (1998), Utveckling och rättvisa - en politik för storstaden på 2000-talet [Development and Fairness - a Policy for the Big City in the 21st Century], Governmental Bill 1997/98:165.

Swedish Government (2018), Strategi för Levande Städer - politik för en hållbar stadsutveckling [Strategy for Liveable Cities - a Policy for the Sustainable Development of Cities], Regeringens skrivelse 2017/18:230.

The Metropolitan Investigation (Storstadsutredningen) (1990), Storstadsliv rika möjligheter - hårda villkor: slutbetänkande [Urban Life: Rich Opportunities Harsh Conditions: Final Report]. SOU 1990:36.

Westlund, H. (2014), 'Urban futures in planning, policy and regional science: Are we entering a post-urban world?', Built Environment, 40 (4), 447-457. 